\title{
Notes on Gentianella tarapacana (Gilg) T.N.Ho \& S.W.Liu (Gentianaceae), endemic to the Chilean Altiplano
}

\section{Notas sobre Gentianella tarapacana (Gilg) T.N.Ho \& S.W.Liu (Gentianaceae), una planta endémica del altiplano chileno}

\author{
Simon Pfanzelt ${ }^{1} \&$ Carolina García ${ }^{2}$ \\ ${ }^{1}$ Institut für Biologie und Umweltwissenschaften, Carl von Ossietzky Universität Oldenburg, Carl-von-Ossietzky-Straße 9-11, \\ 26129 Oldenburg, Germany. \\ ${ }^{2}$ Departamento de Botánica, Universidad de Concepción, Barrio Universitario s/n, Casilla 160-C, Concepción, Chile. \\ simon.pfanzelt@uni-oldenburg.de
}

\begin{abstract}
Over a century after its first collection, Gentianella tarapacana (Gilg) T.N. Ho \& S.W. Liu (Gentianaceae) was rediscovered at its type locality Amincha (Region of Antofagasta, Province El Loa; $21^{\circ} 12^{\prime} \mathrm{S} ; 68^{\circ} 20^{\prime} \mathrm{W}, 3850 \mathrm{~m}$ ). The species is endemic to the Altiplano of northern Chile. It grows in wetland habitats. We designate a lectotype and provide a detailed description of the species, as well as an illustration and floristic information about its habitat at the type locality.
\end{abstract}

KEYwoRds: Northern Chile, Central Andes, Andean wetlands, lectotypification.

\section{RESUMEN}

Después de 125 años, Gentianella tarapacana (Gilg) T.N. Ho \& S.W. Liu (Gentianaceae) fue redescubierta en su localidad

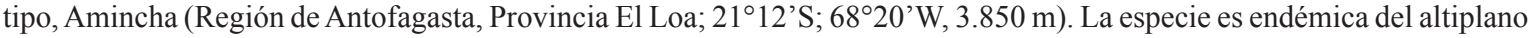
chileno y crece en los bofedales. Se designa un lectotipo y se entrega una descripción detallada y una ilustración de la especie, junto con información florística de la localidad tipo.

Palabras clave: Norte de Chile, Andes centrales, bofedales, lectotipificación.

\section{INTRODUCTION}

In its current generic circumscription, Gentianella comprises ca. 250 mostly alpine species, which are distributed worldwide with the exception of central and southern Africa (Struwe et al. 2002). The center of species diversity lies in the central Andes of South America. The five Chilean species of the genus, G. coquimbensis (Briq.) Martic. et Quezada, G. magellanica (Gaudich.) Fabris ex D.M. Moore, G. multicaulis (Gillies ex Griseb.) Fabris, $G$. ottonis (Phil.) Muñoz, and G. tarapacana (Gilg) T.N. Ho \& S.W. Liu (Pfanzelt, in prep.), belong to an efimbriate, uninectariate lineage that originated in the Eastern Himalayas at the end of the Tertiary and reached the Americas via Beringia (Von Hagen \& Kadereit 2001). The final phase of the Andean uplift during the late Pliocene and early Pleistocene (Gregory-Wodzicki 2000, Kennan et al. 1997, Van der Hammen et al. 1973) created new ecological opportunities in a topographically heterogeneous alpine environment, thus bringing about the rapid diversification of Gentianella. Speciation rates were estimated as of 1.48$3.21 \mathrm{sp} / \mathrm{myr}$ (Von Hagen \& Kadereit 2001), comparing well to the high diversification rates of other genera with a similar biogeographic history, e.g. Lupinus (1.93-2.78 sp/ myr; Hughes \& Eastwood 2006), Astragalus (0.65-2.06 sp/ myr; Scherson et al. 2008) or Valeriana of the north Andean páramo (0.80-1.34 sp/myr; Bell \& Donoghue 2005).

All Chilean Gentianella species grow on wet, but not water-logged soils of high organic content in azonal Andean peat-accumulating wetlands (locally referred to as bofedales; Squeo et al. 2006), with the exception of G. magellanica which is also found in mesic sites of the Patagonian steppe (Skottsberg 1916, Pisano 1977). The flowers of $G$. tarapacana, G. coquimbensis, and G. ottonis are visited by syrphid flies, in the latter case also by bumblebees that may act as possible pollinators (S. Pfanzelt, pers. obs.). 
The type locality Amincha (Region of Antofagasta, Province El Loa; $21^{\circ} 12^{\prime} \mathrm{S}$; 68²0'W, 3850 m, Fig. 1) is an abandoned mining settlement in the Chilean Altiplano $10 \mathrm{~km}$ west of Ollagüe. Amincha is located at the mouth of a small permanent watercourse, the Quebrada Amincha, which has an extension of $5.2 \mathrm{~km}$. Over most of its course, the stream is accompanied by a narrow strip of wetland vegetation. Precipitation in this part of the Altiplano concentrates in January and February, when humid air masses from the tropical lowlands of the Amazonas basin cross the Andes (Garreaud et al. 2003). Mean annual temperature and mean annual precipitation for Ollagüe, recorded during a 7-year interval, are $6.8^{\circ} \mathrm{C}$ and $70.6 \mathrm{~mm}$ respectively (Di Castro \& Hajek 1976). Sulphur mining activities came to a halt in 1992, but a few persons still live in the settlement and use the wetland as pasture for two small alpaca herds of ca. 70 animals (J.M. Mondaca, pers. comm.). Occurrence data of G. tarapacana comprises just the type locality Amincha. were collected and stored in ethanol. Leaf material was sampled for subsequent molecular studies of DNA sequence variation and dried in silica gel (Chase \& Hills 1991). The floristic composition of the azonal wetland and the surrounding zonal vegetation was assessed, since the previous publications of Philippi (1891) and Gilg (1896) do not provide detailed information about the plant species associated with G. tarapacana at the type locality. Standard herbarium procedures were applied during specimen examinations of SGO and ULS that included the isotype material. Photographs of the holotype (F 10402) and that of an isotype deposited in K (K 438980) were seen. LPB herbarium specimens were studied and compared with the collected material, in order to clarify the endemic status of G. tarapacana. Plant nomenclature follows Zuloaga et al. (2008), with some exceptions.

\section{RESULTS}

\section{MATERIALS AND METHODS}

We visited the type locality in January 2010 in order to verify if the species still existed at the site. Two specimen were deposited in CONC. Three fully developed flowers
At the type locality, we found just a single population and counted 29 mostly flowering individuals in an area of ca. 200 $\mathrm{m}^{2}$. Flower buds seem to have broken recently, as a minority of the plants was fully developed. Fruiting specimens were not observed.

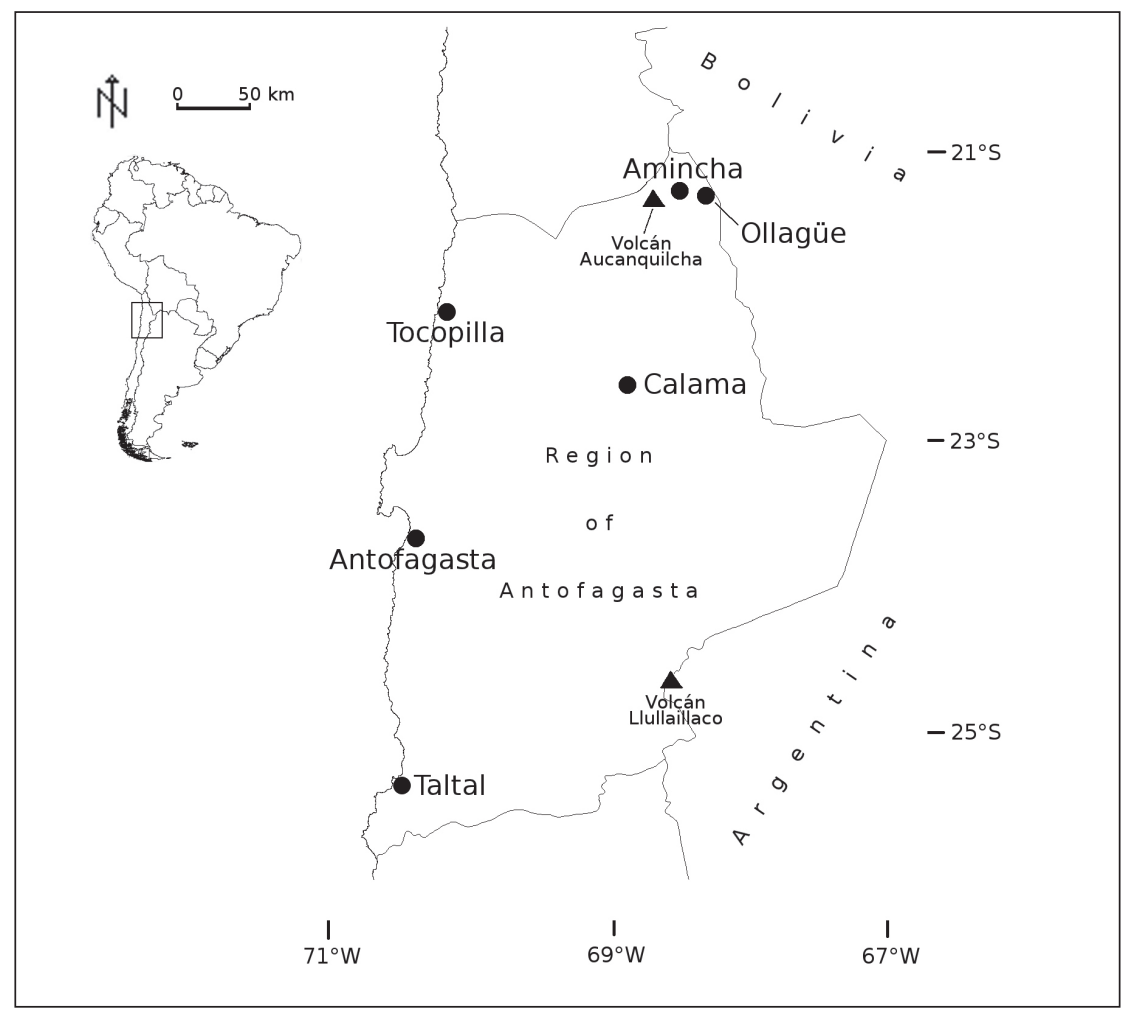

FIGURE 1. Amincha, the type locality of Gentianella tarapacana, is situated in the altiplano of the Region of Antofagasta, northern Chile.

Figura 1. Amincha, la localidad tipo de Gentianella tarapacana, se encuentra en el altiplano de la Región de Antofagasta, norte de Chile. 

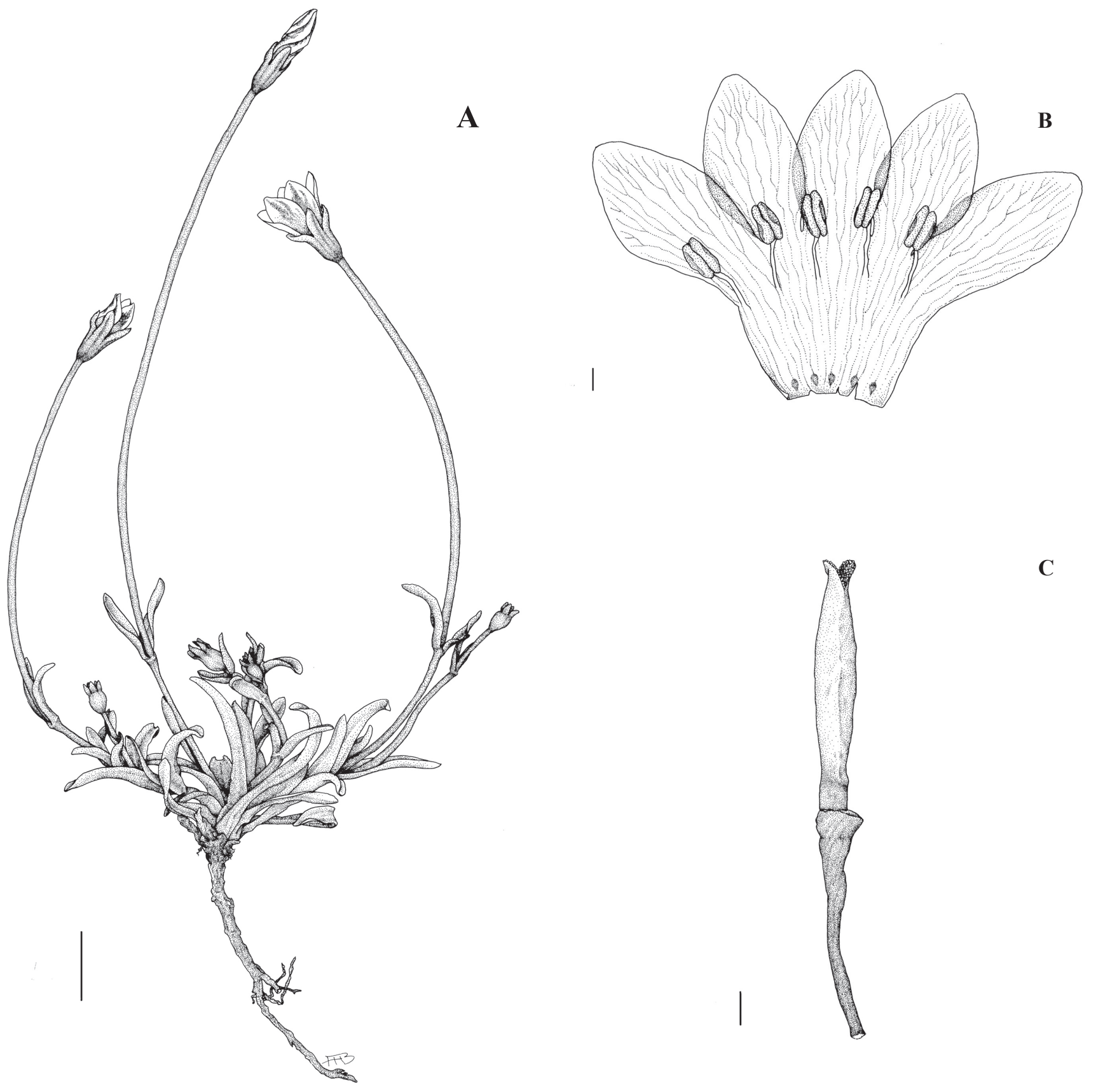

FIgURE 2. Gentianella tarapacana. (a) growth habit, (b) corolla, (c) gynoecium. Scale bars (a) $=1 \mathrm{~cm}$, (b) and (c) $=1 \mathrm{~mm}$. Illustration by F. Herrera Barrandeguy.

Figura 2. Gentianella tarapacana. (a) hábito, (b) corola, (c) gineceo. Escala (a) $=1 \mathrm{~cm}$, (b) y (c) $=1 \mathrm{~mm}$. Ilustración de F. Herrera Barrandeguy. 


\section{DESCRIPTION}

Gentianella tarapacana (Gilg) T.N. Ho \& S.W. Liu

Basionym: Gentiana tarapacana Gilg, Bot. Jahrb. Syst. 22(2): 305. 1896. "Chile, Tarapacá, ad Amincha, 3800 m s. m. (F. Philippi).”

Annual or biennial herb, erect, glabrous, tap-rooted, up to 18 cm high (Fig. 2a). 1-6 stems from the base, mostly unbranched (when branched, then in the lower third), bearing a terminal and sometimes 1-2 axillary flowers. Stem diameter 1.5-2.4 $\mathrm{mm}$, subtetragonal, often suffused with dark purple. Leaves opposite, parallel-nerved, of bitter taste, the basal portion abaxially often tinged dark purple; interpetiolar line present; basal leaves closely spaced and crowded but not always forming a well-developed basal rosette, oblong-obovate to oblong-spatulate, entire, apex acute, gradually tapering towards the base, $24.0-26.0 \times 3.5-4.6 \mathrm{~mm}$; cauline leaves few, sessile, oblong, entire, apex rounded, 11.0-19.0 x 2.4$4.9 \mathrm{~mm}$. Inflorescence a solitary flower or a few-flowered lax cyme. Flowers perfect, actinomorphic, pentamerous, very rarely hexamerous, gamopetalous, gamosepalous, diurnal, entomophilous, pedicels $3.2-15.7 \mathrm{~cm}$ long. Calyx funnelform, often suffused with dark purple, intracalycine membrane absent, 6.2-11.5 mm long, lobes mostly shorter than the tube; tube well developed, 3.5-5.9 mm long; calyx lobes oblong-ovate, apex acute, 2.7-6.5 x 0.9-1.2 mm long. Corolla persistent, plicae absent, aestivation convolute, infundibuliform to hypocrateriform, divided to more than half the petal length; expanded limb 14-21 mm across, corolla 10.9-17.0 mm long; corolla tube without trichomes, fimbriae or scales; petals ovate, apex acute, the basal portion light green to yellowish, the distal portion white with a dark purple patch and streaks on the abaxial face, giving the flower a greyish appearance in the field when seen from above, petal margins slightly involute (Fig. 2b). One nectary per corolla lobe at the base of the corolla tube, V- to U-shaped. Stamens equal, included; filaments inserted at ca. 2/3-3/4 the length of the corolla tube, 4.2-5.2 $\mathrm{mm}$ from the base, the free portion 2.5-2.9(-4.0) mm long, light green, slightly flattened. Anthers versatile, yellow, 1.3-1.9 mm long. Ovary superior, sessile to subsessile, cylindrical, light green, bicarpellate, unilocular, 7.7-9.7 x $1.3 \mathrm{~mm}$; style indistinct, stigma deeply two-lobed, stigmatic lobes rounded, pappilose, 0.8-0.9 x 0.5$0.9 \mathrm{~mm}$ (Fig. 2c). Fruit a bivalved capsule, dehiscent at the apex (not seen at maturity). Seeds unknown.

\section{Material Studied}

Chile: Region of Antofagasta, Prov. El Loa, Quebrada Amincha, 3920 m, 26.I.2010, S. Pfanzelt \& C. García 440 (CONC); Amincha, II.1885, F. Philippi s/n (SGO 41950 - isotype!); Amincha, 25.II.1885, F. Philippi s/n (SGO 53930 - lectotype!, here designated); Amincha, F. Philippi s/n (SGO 53931 - isotype!); Amincha, 3800 m, F. Philippi s/n (F 10402 - holotype, photography in CONC!);
Amincha, 3800 m, F. Philippi s/n (K 438980 - isotype, photography!)

\section{DISCUSSION}

The type specimen of $G$. tarapacana was collected by Federico Philippi in Amincha in February 1885 on his journey through the regions of Antofagasta and Tarapacá in northern Chile(Muñoz \& Prina 1987). RudolfoA. Philippi(1891) cited the material as Gentiana primulifolia Griseb. Presumably, Philippi consulted Grisebach's (1838, 1845) monographs of the Gentian family and/or Weddell (1859) for species determination. With regards to the corolla colouration of $G$. primulifolia, Grisebach $(1838,1845)$ appeared to be in doubt, as he described it as "purpurascentis?" and "purpureae?", respectively, whereas Weddell (1859) mentions the corolla to be "d'un blanc jaunâtre en dedans, à lobes plus ou moins lavés de violet en dehors". G. primulifolia, however, has a red-yellow corolla and is endemic to the Andean grasslands of south-central Peru (Brako \& Zarucchi 1993). Gilg (1896) described Gentiana tarapacana Gilg based on the Amincha material. In his publication, he cited "Gentiana primulifolia Phil. (...), non Griseb.”, a name that has never been validly published. Ho \& Liu (1993) transferred the species to the genus Gentianella.

As the holotype (B) was destroyed during the Second World War (R. Vogt, pers. comm.), the isotype SGO 53930 is designated here as the lectotype.

Gentianella tarapacana shares with G. coquimbensis, which is endemic to wetlands of the Chilean Andes between $28^{\circ} 44^{\prime}-30^{\circ} 23^{\prime} \mathrm{S}$, the following characters: growth habit with one to few stems from the base, mostly solitary flowers, corolla tube colouration, and calyx lobe shape, but differs in corolla lobe colouration, and in missing trichomes in the basal part of the corolla tube. Gentianella tarapacana presents affinities to scapose Gentianella species of the Bolivian and Argentinian Altiplano. These are (with the distinctive character states in parenthesis; Fabris 1983, Filippa \& Barboza 2006): G. fiebrigii (Gilg) Holub (2-7 $\mathrm{cm}$ high, corolla lobes are shorter than or equal the tube, ovary shortly stipitated), G. hieronymi (Gilg) Fabris (3-8 $\mathrm{cm}$ high, ovary stipitated), G. meyeniana (Griseb.) Fabris (2-6 cm high, leaves linear-spatulate, calyx lobes obtuse) and G. pseudocrassula (Gilg) Fabris (calyx lobes triangular, corolla lobes 2-3 times longer than the tube).

\section{WETLAND VEGETATION}

Floristic studies of Chilean Altiplano wetlands were published by Ackermann (2001), Luebert \& Gajardo (2000), and Ruthsatz (1993, 1995). The Quebrada Amincha wetland contrasts sharply with the surrounding arid puna vegetation and harbours more than 20 vascular plant species. Using a preliminary habitat classification, we can distinguish three 
groups: i) submerged, emergent or floating freshwater species (macrophytes), ii) vegetation forming dense cushions on peaty soil saturated permanently or seasonally with moisture, and iii) transition vegetation between moist and dry soil.

i) Macrophytes like Myriophyllum quitense Kunth, Lemna gibba L., and Ranunculus uniflorus Phil. ex Reiche occur in open water.

ii) Along a gradient of soil moisture species like Lobelia oligophylla (Wedd.) Lammers, Mimulus depressus Phil., and Ranunculus exilis Phil. dominate the wet extreme of the gradient, with the sporadic occurrence of Werneria pygmaea Gillies ex Hook. et Arn., whereas Zameioscirpus atacamensis (Phil.) Dhooge et Goetgh., Juncus stipulatus Nees et Meyen, Eleocharis pseudoalbibracteata S. González et Guagl., Puccinellia frigida (Phil.) I.M. Johnst., Poa sp., Arenaria rivularis Phil., and Lilaeopsis macloviana (Gand.) A.W. Hill constitute the dominant elements on soils with less moisture, being accompanied by Colobanthus quitensis (Kunth) Bartl., Plantago tubulosa Decne., Gentianella tarapacana, Gentiana prostrata Haenke, and Epilobium sp.

iii) A transition vegetation on soils with less organic matter next to the watercourse includes Deyeuxia eminens J. Presl, Distichlis humilis Phil., and Festuca orthophylla Pilg., that form a "bunch-grassland swamp" (Molina et al. 2007). The latter species is found also in the arid puna. In Quebrada Amincha, the regular burning of the bunch grasses is a common practice as it induces new shoot growth for animal forage (J.M. Mondaca, pers. comm.).

ZONAL PUNA VEGETATION

Evergreen or drought-deciduous resinous shrubs and tussock grasses compose the zonal arid vegetation. This formation is characteristic of a "Puna Ecosystem" (Villagrán et al. 1981, García \& Beck 2006) and according to Teillier (1998) it shows strong floristic links to a regional puna flora extending from southern Peru and western Bolivia to northern Chile and Argentina. The scrubland of varying height and vegetation cover is constituted by species like Parastrephia lucida (Meyen) Cabrera, P. quadrangularis (Meyen) Cabrera, Fabiana denudata Miers, Chersodoma candida Phil., and Baccharis tola Phil. Less abundant are Junellia seriphioides (Gillies \& Hook.) Moldenke, Adesmia spinosissima Meyen, F. squamata Phil., Senecio nutans Sch. Bip., and the cushion plant Pycnophyllum sp. Sparsely scattered individuals of Polylepis tarapacana Phil. can be found as well. Between the rocks of the canyon walls grow Mutisia ledifolia Decne. ex Wedd., Haplopappus rigidus Phil., Senecio rosmarinus Phil., S. madariagae Phil., Caiophora sp., Solanum sp., Urtica sp., Cheilanthes pruinata Kaulf., and Notholaena nivea (Poir.) Desv. A second Solanum species, S. metarsium C.V. Morton, prefers sandy soils of the canyon base.

\section{Conservation}

Maybe the restricted distribution accounts for the small number of $G$. tarapacana collections that have been made so far, in addition to a relatively low sampling effort in those regions of the Altiplano that are beyond vehicular access. Due to insufficient data, the species has not yet been formally assigned to a conservation category and the Amincha site does not belong to any protected area within the Chilean National Park and Reserve System (SNASPE). Cavieres et al. (2002) regard the central Province El Loa as a priority area for conservation with an elevated number of endemic species. As high mountain wetland ecosystems are extremely susceptible to climatic change and human disturbance (Squeo et al. 2006), the upcoming establishment of the Alto Loa National Reserve (DAPMA, CONAF Region of Antofagasta, pers. comm.) represents a valuable contribution to the conservation of Altiplano ecosystems.

\section{ACKNOWLEDGEMENTS}

The authors wish to thank J.M. Mondaca, C. Heibl, K.B. von Hagen, and the curators of CONC, SGO and ULS. Funding of the Dr. Karl Wamsler-Stiftung is gratefully acknowledged.

\section{REFERENCES}

Ackermann, M. 2001. Die Vegetation der Bachläufe in der Hochatacama (II. Region) in Chile. Diploma thesis, University of Marburg, Germany.

Bell, C.D. \& M.J. Donoghue. 2005. Phylogeny and biogeography of Valerianaceae (Dipsacales) with special reference to the South American valerians. Organisms, Diversity and Evolution 5(2): 147-159.

Brako, L. \& J.L. Zarucchi. 1993. Catalogue of the Flowering Plants and Gymnosperms of Peru. Monographs in Systematic Botany from the Missouri Botanical Garden 45: i-xl, 1-1286.

Cavieres, L.A., M.T.K. Arroyo, P. Posadas, C. Marticorena, O. Matthei, R. Rodríguez, F.A. Squeo \& G. Arancio. 2002. Identification of priority areas for conservation in an arid zone: application of parsimony analysis of endemicity in the vascular flora of the Antofagasta region, northern Chile. Biodiversity and Conservation 11: 1301-1311.

Chase, M.W. \& H.H. Hitls. 1991. Silica gel: An ideal material for field preservation of leaf samples for DNA studies. Taxon 40: 215-220.

Di Castri, F. \& E.R. HajeK. 1976. Bioclimatología de Chile. Editorial de la Universidad Católica de Chile, Santiago de Chile. $161 \mathrm{pp}$.

Fabris, H.A. 1983. Gentianaceae. En: A.L. Cabrera, Flora de la Provincia de Jujuy 13(8), pp. 55-83. Colección Científica del Instituto Nacional de Tecnología Agropecuaria. Buenos Aires, Argentina.

FilipPA, E. \& G. E. BarbozA. 2006. Gentianaceae. En: A.M. Anton 
\& F.O. Zuloaga, Flora Fanerogámica Argentina 102, pp. 1-46. Proflora Conicet. Córdoba, Argentina.

García, E. \& S.G. Beck. 2006. Puna. En: M. Moraes, B. Øllgaard, L.P. Kvist, F. Borchsenius \& H. Balslev (eds.), Botánica Económica de los Andes Centrales, pp. 51-76. Universidad Mayor de San Andrés, La Paz, Bolivia.

Garreaud, R., M.Vuille \& A.C. Clement. 2003. The climate of the Altiplano: observed current conditions and mechanisms of past changes. Palaeogeography, Palaeoclimatology, Palaeoecology 194: 5-22.

GILG, E. 1896. Beiträge zur Kenntnis der Gentianaceae. I. Bot. Jahrb. Syst. 22(2): 301-347.

Grisebach, A.H.R. 1838. Genera et Species Gentianearum adjectis Observationibus Quibusdam Phytogeographicis. J.G. Cotta, Stuttgart, Germany. 364 pp.

Grisebach, A.H.R. 1845. Gentianaceae. In: A. de Candolle, Prodromus Systematis Naturalis Regni Vegetabilis 9: 38141, 561-563. Paris, France.

Gregory-Wodzicki, K.M. 2000. Uplift history of the Central and Northern Andes: A review. Geological Society of America Bulletin 112(7): 1091-1105.

Hagen, K.B. von \& J.W. Kadereit. 2001. The phylogeny of Gentianella (Gentianaceae) and its colonization of the southern hemisphere as revealed by nuclear and chloroplast DNA sequence variation. Organisms, Diversity and Evolution 1: 61-79.

Hammen, T. van der, J.H. Werner \& H. van Dommelen. 1973. Palynological record of the upheaval of the Northern Andes: a study of the Pliocene and Lower Quaternary of the Colombian Eastern Cordillera and the early evolution of its High-Andean biota. Review of Palaeobotany and Palynology 16(1-2): 1-122.

Ho, T.N. \& S.W. LiU. 1993. New combinations, names and taxonomic notes on Gentianella (Gentianaceae) from South America and New Zealand. Bulletin of the Natural History Museum. Botany series. London 23(2): 61-65.

Hughes, C. \& R. EAstwood. 2006. Island radiation on a continental scale: Exceptional rates of plant diversification after uplift of the Andes. Proceedings of the National Academy of Sciences 103(27): 10334-10339.

Kennan, L., S.H. Lamb \& L. HoKe. 1997. High-altitude palaeosurfaces in the Bolivian Andes: evidence for late cenozoic surface uplift. In: M. Widdowson, Palaeosurfaces: Recognition, Reconstruction and Palaeoenvironmental Interpretation, pp. 307-323. Geological Society Special Publication No. 120. Bath, United Kingdom.

Luebert, F. \& R. Gajardo. 2000. Vegetación de los Andes áridos del norte de Chile. Lazaroa 21: 111-130.

Molina, J.A., G.. Navarro, N. de la Barra \& A. Lumbreras. 2007. Andean aquatic vegetation in central Bolivia. Phytocoenologia 37(3-4): 753-768.
Muñoz, M. \& A.O. Prina. 1987. Nota aclaratoria sobre especies colectadas por Federico Philippi en su viaje a Tarapacá. Noticiario Mensual, Museo Nacional de Historia Natural 313: 2-17.

Philippi, R.A. 1891. Verzeichniss der von Friedrich Philippi auf der Hochebene der Provinzen Antofagasta und Tarapacá gesammelten Pflanzen. F.A. Brockhaus, Leipzig, Germany. $96 \mathrm{pp}$.

Pisano, E. 1977. Fitogeografía de Fuego-Patagonia chilena. I.Comunidades vegetales entre las latitudes 52 y $56^{\circ} \mathrm{S}$. Anales del Instituto de la Patagonia 8: 121-250.

Ruthsatz, B. 1993. Flora und ökologische Bedingungen hochandiner Moore Chiles zwischen $18^{\circ} 00^{\prime}$ (Arica) und 40³0' (Osorno) südlicher Breite. Phytocoenologia 23: 157-199.

Ruthsatz, B. 1995. Vegetation und Ökologie tropischer Hochgebirgsmoore in den Anden Nord-Chiles. Phytocoenologia 25(2): 185-234.

Scherson, R.A., R. Vidal \& M.J. Sanderson. 2008. Phylogeny, biogeography, and rates of diversification of New World Astragalus (Leguminosae) with an emphasis on South American radiations. American Journal of Botany 95(8): 1030-1039.

Skottsberg, C. 1916. Botanische Ergebnisse der schwedischen Expedition nach Patagonien und dem Feuerlande, 1907-1909. V. Die Vegetationsverhältnisse längs der Cordillera de los Andes S. von $41^{\circ} \mathrm{S}$. Br. Kungliga Svenska Vetenskapsakademiens Avhandlingar i Naturskyddsärenden. Stockholm 56(5): 3-325.

Squeo, F.A., B.G. Warner, R. Aravena \& D. Espinoza. 2006. Bofedales: high altitude peatlands of the central Andes. Revista Chilena de Historia Natural 79: 245-255.

Struwe, L., J.W.,Kadereit, J. Klackenberg, S. Nilsson, M. Thiv, K.B. von Hagen \& V.A. Albert. 2002. Systematics, character evolution, and biogeography of Gentianaceae, including a new tribal and subtribal classification. In: L. Struwe \& V.A. Albert (eds.), Gentianaceae: systematics and natural history, pp. 21-309. Cambridge University Press, Cambridge, United Kingdom.

Teillier, S. 1998. Flora y vegetatión alto-andina del área de Collaguasi-Salar de Coposa, Andes del norte de Chile. Revista Chilena de Historia Natural 71: 313-329.

Villagrán, C., J.J. Armesto \& M.T.K. Arroyo. 1981. Vegetation in a high Andean transect between Turi and Cerro León in Northern Chile. Vegetatio 48: 3-16.

WedDell, H.A. 1859. Chloris Andina: essai d'une flore de la région alpine des Cordillères de l'Amérique du Sud, vol. 2. P. Bertrand, Paris, France. 316 pp.

Zuloaga, F.O., O. Morrone \& M.J. Belgrano(eds.). 2008. Catálogo de las Plantas Vasculares del Cono Sur. Monographs in Systematic Botany from the Missouri Botanical Garden 107: 1-3348.

Recibido: 10.01.11

Aceptado: 19.04.11 